Вісник Дніпропетровського університету. Серія: геологія, географія. 2016. 24 (1), 54-64.

Vìsnik Dnìpropetrovs'kogo unìversitetu. Serîa geologîâ, geographìâ

Dnipropetrovsk University Bulletin. Series geology, geography. 2016, 24 (1), 54-64.

doi: $10.15421 / 111609$

http://geology-dnu.dp.ua

УДК 502.2.05+58.009+581.93+582.893.6 (477.63)

\title{
Родина селерових (Аріасеае) у флорі Орільського національного природного парку
}

\section{В. В. Манюк}

Дніпропетровський національний університет імені Олеся Гончара, Дніпропетровськ, Украӥна, e-mail: oril.npp.mv@gmail.com

Уперше для Приорілля як важливого природного субрегіону у складі Степового Подніпров'я складено й опрацьовано повний список флори для однісї з провідних родин - Аріасеае. Виявлено місцезростання нових для Приорілля регіонально рідкісних видів: Bupleurum tenuissimum L., Angelica palustris (Besser) Hoffm., Selinum carvifolia (L.) L. Здійснено уточнений аналіз спектра географічних елементів та їх співвідношення по різних еколого-ценотичних групах, які представлені у Приоріллі бореально-лучними, галофільно-лучними, лісовими, рудерально-лісовими, узлісними, водно-болотними, степовими та псамофільно-степовими видами Аріасеае. На підставі аналізу ролі зонтичних у природних рослинних угрупованнях запропоновано додати до Червоного списку Дніпропетровщини ряд нових видів із родини Аріасеае, а також розробити окремий список видів-ценозоутворювачів, які потребують особливих природоохоронних заходів попри їх значне поширення.

Ключові слова: національний природний парк, Аріасеае, флора, долина річки Оріль, ареал, ценопопулячія

\section{Apiaceae family in the flora of Orilsky national nature park}

\author{
V. V. Manyuk \\ Oles Honchar Dnepropetrovsk National Univesuty,Dnepropetrovsk, Ukraine, e-mail: oril.npp.mv@gmail.com
}

The article contains the results of a comprehensive study of distribution and coenotical affinity for species of Apiaceae family (Magnoliophyta) in the valley r. Oril as well, as national park "Orilsky" is designed on this area. A complete list of flora for one of leading plant family Apiaceae for designing national park is done and processed in the first time for Oril valley as important natural area of Steppe Podniprov'ya nature region. Specified chorological analysis of geographical elements and their relationship to various environmental and cenotic groups represented in Oril basin (boreal-meadow, halophilic-meadow, forest, forest-ruderal, freshwater, marsh, steppe and sand-steppe species) Apiaceae is done. It is discovered new sites for regionally rare species such as Bupleurum tenuissimum L., Angelica palustris (Besser) Hoffm., Berula erecta (Huds.) Coville, Selinum carvifolia (L.) $L$. On the basis of analysis of role of Apiaceae in natural vegetable groupments it is suggested to add to the Red list of Dnipropetrovsk region the row of new species from the family of Apiaceae, and also to develop the separate list of constructionspecies of main natural cenoses which need the special nature protection measures without regard to their wide distribution.

Keywords: national nature park, flora, river Oril valley, area, coenopopulation

Вступ. Створення нових природоохоронних установ високого рангу, у складі яких під охорону беруться значні за площею території, стимулює нові дослідження природного біорізноманіття, зокрема, встановлення видового складу різних таксономічних груп, характеру поширення видів у межах заповідних територій, ценотичного розподілу та стану популяцій. При цьому з розширенням мережі національних парків і заповідників поява кожного нового природоохоронного об'єкту додає новий інформаційний пул на хорологічних мапах, оскільки супроводжується завжди складанням інвентаризаційних списків видів уже або на етапі створення національного парку (заповідника), або на перших етапах його функціонування. Крім того, зосередження дослідницької уваги на конкретних територіальних комплексах у межах національних парків та заповідників забезпечує можливості для більш детального вивчення внутрішньої структури ареалів, отримання актуальних даних про чисельність популяцій, а відповідно й реальний созологічний 
статус видів, а також про обсяги біомаси і динаміку змін цих показників для видів біоти, які населяють території національних парків та заповідників.

3 іншого боку, можливості для вивчення хорології та популяційної біології видів біоти поза межами установ природно-заповідного фонду в Україні обмежені винятково особистою ініціативою і власними ресурсними можливостями окремих дослідників і тому не мають системного характеру. Зокрема, щодо флори судинних рослин України, попри наявність величезного обсягу фактичного матеріалу про поширення видів у пї межах, сучасний рівень відображення хорологічної інформації, особливо щодо внутрішньої структури ареалів, залишається для більшості видів неповним і не відповідним реальній ситуації, що унеможливлює виконання таких стратегічних для сучасної консерваційної охорони природи завдань, як оцінювання природоохоронного статусу видів, виділення ключових ботанічних територій, розроблення менеджмент-планів щодо збереження популяцій, визначення запасів цінних у ресурсному відношенні видів тощо.

Виконання у 2015 році проекту створення Орільського національного природного парку на Лівобережжі Дніпра, біля північної межі степової зони України, супроводжувалося флористичними дослідженнями, які охопили достатньо велику і цілісну у фізико-географічному відношенні територію басейну р. Оріль, що дало можливість скласти перший узагальнений список флори для Приорілля (тільки в межах Дніпропетровської області). Щодо деяких таксономічних груп, отримано достатньо інформації для того, щоб установити характер поширення видів, чисельність (трапляння) та ценотичну приуроченість на різних ділянках проектованого парку. Зважаючи на великі розміри території проектованого парку, у межах якої теоретично могло сформуватися декілька різних елементарних флор, доцільне послідовне опрацювання флористичного різноманіття за окремими таксономічними групами, зокрема, диференційованого підходу потребують перш за все провідні за видовим багатством родини судинних рослин - айстрові, тонконогові, бобові, капустяні, гвоздикові, губоцвіті.

Однією з таких груп є родина зонтичних, або селерових - Apiaceae, яка посідає десяте місце за загальною кількістю видів у флорі Дніпропетровської області. Саме цю родину обрано першою для еколого-географічного аналізу флори проектованого національного парку, 3 декількох причин. По-перше, за результатами досліджень території майбутнього парку виявлено значні за площею ділянки, де представники родини Аріасеае виступають або домінантами чи субдомінантами, або навіть за відносно невисокої щільності популяцій $€$ постійним компонентом фактично всіх головних рослинних формацій, представлених у Приоріллі. По-друге, наразі зонтичні - більш вивчена група порівняно $з$ іншими провідними родинами флори басейну р. Оріль. Крім того, протягом 2015 року під час польових досліджень було здійснено ряд нових регіонально цінних флористичних знахідок, зокрема, виявлено місцезростання двох нових для території Дніпропетровської області видів Арiaceae, які безумовно становлять науковий інтерес.

Матеріал і методи досліджень. Основою для еколого-географічного аналізу родини Арiaceae у флорі Орільського національного природного парку слугували матеріали польових маршрутних та напівстаціонарних (на ключових ділянках проектованого парку) досліджень флори та рослинного покриву, здійснених протягом 2015 року. Найбільшу кількість маршрутів здійснено в період з другої половини липня до кінця вересня, загалом дослідження охоплювали період із початку квітня до кінця листопада. Крім того, до уваги було взято дані щодо поширення окремих видів Аріасеае в долині р. Оріль, накопичені автором за період з 1997 року. Найбільш продуктивними у минулі роки були ботанічні роботи у складі експедицій еколого-туристичного об'єднання «Орлан», здійснені у 1997-2001 pр., а також у складі спільної експедиції геолого-географічного факультету ДНУ імені Олеся Гончара та Обласного екологонатуралістичного центру дітей та учнівської молоді «Боривітер», яка працювала у червні 2013 року в Царичанському районі.

Повний список видів зонтичних для майбутнього національного парку складено також з урахуванням усіх літературних даних, головними джерелами для цього були монографічна «Флора Дніпропетровської та Запорозької областей..» В. В. Тарасова (Tarasov, 2005), публікації Б. О. Барановського (Baranovsky, 2013; 2015), фундаментальні регіональні флористичні праці І. Я. Акінфієва (Akinfiev, 1889) та В. М. Сидорова (Sidorov, 1897) кінця ХІХ ст., а також низка статей О. Л. Бельгарда (Belgard \& Kirichenko, 1940), О. А. Сліашевич (Eliashevych, 1937) та Є. І. Пестушко (Pestushko, 1937) першої половини ХХ ст. Останні із зазначених публікацій особливо цікаві тим, що містять достатньо детальні дані про структуру рослинних асоціацій (перш за все лучних) і відповідно деякі дані про ценотичну роль видів родини зонтичних у формуванні тогочасного рослинного покриву долин Орелі і Дніпра в районі, де тепер створюється 
національний природний парк «Орільський». Для усіх знахідок 2015 року визначено точні географічні координати, які надалі можуть бути використані для точних популяційних та хорологічних досліджень за флорою і рослинним покривом Приорілля, а також для розроблення природоохоронних стратегій для збереження природного фіторізноманіття як на теренах майбутнього національного парку, так і в ширшому вимірі для регіону Степового Подніпров’я в цілому.

Результати та ї аналіз. В.В. Тарасов у «Флорі Дніпропетровської та Запорозької областей» (Tarasov, 2005) наводить усього 57 видів Арiaceae, чотири 3 яких уперше і востаннє наводили І. Я. Акінфієв та В. М. Сидоров понад 120 років тому, а сім видів $€$ в умовах регіону винятково культурантами. 3 урахуванням достатньо поширеного в останні роки в культурі фенхеля (Foeniculum vulgare Mill.), а також двох нових для області видів автохтонної флори, виявлених у 2015 р. у природних фітоценозах Приорілля, повний список видів зонтичних у флорі Дніпропетровщини складає 61 вид, з яких 53 види належать до спонтанної флори. Без урахування не підтверджених за 100 років чотирьох видів зі списків І. Я. Акінфієва і В. М. Сидорова (Bupleurum rotundifolium L., Ferulago galbanifera (Mill.) W.D.J Koch, Physospermum cornubiense (L.) DC. i Trinia hispida $H o f f m$.) сучасна флора зонтичних Дніпропетровської області складає 57, а без культурантів - 49 видів. При цьому у флорі проектованого національного природного парку виявлено зростання 45 видів зонтичних, з яких 37 належать до спонтанної флори. Таким чином, у майбутньому національному парку зосереджено 75,5 \% усього видового різноманіття (спонтанної фракціi) Аріасеае, виявленого на території Дніпропетровської області. На родовому рівні зонтичні Приорілля представлені 24 родами ( 330 представлених у флорі Дніпропетровщини).

За основу для складання наведеного в даній роботі видового списку Аріасеае обрано номенклатуру видових назв за міжнародною базою таксономічних назв рослин «The Plant List» (2013), узгодженою 3 «The International Plant Names Index» (IPNI), зважаючи на їх універсальність для користувачів усього світу, високий рівень верифікації даних і вільний доступ. Згідно зі списками прийнятих «The Plant List» назв Taeniopetalum та Xantoselinum не визнаються окремими родовими таксонами, а Ostericum palustrum наводиться у статусі виду в роді Angelica. За прийнятою для території України номенклатурою С. Л. Мосякіна і M. М. Федорончука (Mosyakin S. L. \& Fedoronchuk M M., 1999) кількість родів Apiaceae у флорі Приорілля складає 26, а за умови визнання самостійності роду Macroselinum (Schur) - 27. Слід зазначити, що до складу флори Орільського національного парку на даному етапі не віднесено регіонально рідкісний вид Cenolophium denudatum (Hornem.) Tutin., дві ізольовані ценопопуляції якого було виявлено наприкінці 1990-х років у басейні р. Оріль, але поза проектованими межами національного природного парку.

Нижче наведено анотований список видів родини Аріасеае для території проектованого Орільського національного природного парку за латинською абеткою. Для кожного виду наводиться назва (жирним курсивом - прийнята «The Plant List», далі курсивом у дужках - загальноприйнята латинська назва в Україні (якщо вона відрізняється від визнаної «Т Те Plant List») і українська наукова назва (курсивом). Оскільки територія проектованого національного парку розташована у межах п'яти адміністративних районів Дніпропетровської області, у списку для кожного виду зазначаються ті 3 них, в яких вид достовірно спостерігався протягом останніх років або реєструвався за літературними даними. Скорочення назв районів означають: Юр. - Юр'ївський, Новом. - Новомосковський, Магд. - Магдалинівський, Царич. - Царичанський, Петрик. - Петриківський.

Відповідність загального ареалу видів певним видам геоелементів по можливості наведено за Ю. Д. Клеоповим, для інших видів (відсутніх у монографії Ю. Д. Клеопова) - за Н. Meusel (1965) з урахуванням деяких нових даних щодо ареалів цих видів. Для остаточного визначення геоелемента у суперечливих випадках також ураховували характеристики типу ареалу за іншими джерелами (перш за все регіональними флористичними працями В. В. Тарасова і Б. О. Барановського (Tarasov, 2005; Red Data Book of Dn., 2010), B. В. Кучеревського (Kucherevskyi, 2004). Ценотична приналежність наводиться 3 дотриманням принципів О. Л. Бельгарда щодо виділення ценоморф, але з використанням для цього українізованих прикметникових епітетів. Самі ценоморфи наведено з урахуванням ценотичної приуроченості видів саме в умовах Приорілля, для більш вивчених видів також наведено тип динамічної поведінки в рослинному покриві досліджуваного району за С. М. Розумовським (Razumovsky, 1981) та I. Б. Кучеровим (Kucherov, 2000). Характеристика кожного виду завершується відомостями про його нинішній созологічний статус і рекомендаціями щодо подальших змін статусу для подальшої організації консерваційних та протекційних заходів зі збереження видів та їх угруповань на регіональному рівні. 
Для видів, які наводяться вперше для Приорілля або є рідкісними в регіоні, наводяться додаткові відомості щодо їх поширення та стану популяцій в умовах проектованого національного природного парку «Орільський».

\section{Анотований список видів родини Аріасеае у флорі проектованого національного природного парку «Орільський»}

1. Aegopodium podagraria L. - Яглиия звичайна. Південносибірсько-середньоазійсько-європейський. Райони: Юр., Новом., Магд., Царич., Петрик. Неморальний (за деякими джерелами - рудеральнолісовий). Характерний вид групи дубово-яглицевих лісових асоціацій. Зрідка. Ценофіл із вузьким спектром. Популяції в ценозах стійкі, нормального типу. Необхідно взяти під охорону як важливий елемент природних лісових фітоценозів.

2. Aethusa cynapium L. - Собача петрушка звичайна. Європейський. Райони: Новом., Магд., вірогідно також у Царич. і Петрик. Рідко. Бореальнонеморальний. У Приоріллі недостатньо вивчений. Достовірно тільки з середньої течії р. Оріль. Підлягає охороні на регіональному рівні.

3. Angelica palustris (Besser) Hoffm. (Ostericum palustre (Besser) Besser) - Дудник (маточник) болотяний. Центросхідноєвропейсько-південносибірський. Район: Царич. Дуже рідко. Цей вид наводиться вперше для долини р. Оріль і для всієї лівобережної частини Дніпропетровської області (на правобережжі відома єдина знахідка криворізьких ботаніків 2000 р. в заплаві р. Самоткань (Red Data Book of Dn., 2010). Одну ценопопуляцію (рис. 2, а-в) у серпні 2015 року виявлено на сіножатній вологій підлісній луці на межі Дніпропетровської та Полтавської областей і відповідно біля межі проектованого національного парку (рис. 1). Під час спостереження більшість рослин вегетували після покосу (в отаві), деяка частина рослин квітувала. Червона книга Дніпропетр. обл. («зникаючий»).

4. Angelica sylvestris L. - Дудник лісовий. Європейсько-південносибірсько-палеобореальний. Райони: Магд., Новом. Узлісно-лісовий. Єдине достовірне місцезнаходження було відоме 3 вологого узлісся бору біля с. Йосипівка у 1998 р. (рис. 1). Рано навесні 2016 року було виявлено новий локалітет виду на межі проектованого національного парку з Харківською областю, неподалік с. Багате, на заболоченому узліссі заплавної діброви. Дуже рідко. Червона книга Дніпропетр. обл. («вразливий»).

5. Anthriscus cerefolium (L.) Hoffm. - Бугила довгоносикова (кервель). Циркумевксинський (балкансько-кримсько-кавказько-малоазійський). Райони: Юр., Новом., Магд., Царич., Петрик. Рудеральнолісовий. Вид, який активно розселяється в регіоні в останнє десятиліття.

6. Anthriscus sylvestris (L.) Hoffm. - Бугила лісова. Європейський. Райони: Юр., Новом., Магд., Царич., Петрик. Неморальний (рудерально-лісовий). Значно поширений по всій території, популяції численні i стабільні. Ценофіл із широким спектром. Охорони не потребує.

7. Berula erecta (Huds.) Coville (Siella erecta (Huds.) M. Pimen.). - Берула (сієла) пряма. Свропейський. Район: Царич. Болотно-водний, реофільний (особливо на ділянках русла із завалами з дерев). Уперше цей вид відмітив у Дніпропетровській обл. у 1984 p. Б. О. Барановський у 1984 p. (Red Data Book of Dn., 2010), пізніше він реєстрував берулу в басейні p. Самара та новому гирлі р. Оріль (ок. сел. Обухівка). B. В. Кучеревський (Kucherevskyi, 2004) зазначає, що цей вид поширений «по всій території» Правобережного Степового Подніпров'я. У долині р. Оріль берулу вперше виявлено достовірно в 2015 р., на ділянці русла р. Оріль між сс. Маячка (Полтавська обл.) і Могилів (Царичан. р-н). Червона книга Дніпропетр. обл. («рідкісний»).

8. Bupleurum tenuissimum L. - Ласкавеизь найтонший. Європейсько-середземноморський. Район: Царич. Степовий, недостатньо вивчений в умовах Степового Подніпров'я. Галофільний. Перша для Дніпропетровської області знахідка цього виду невелика ділянка на остепненій солонцюватій луці на другому рівні заплавної тераси р. Орелі, біля с. Турове (рис. 1), у серпні 2015 року. Виявлено декілька десятків генеративних рослин (рис. 2, г-е). Потребує подальшого дослідження і внесення до Червоного списку Дніпропетр. обл. (зі статусом «невизначений»).

9. Chaerophyllum bulbosum L. - Бутень бульбистий. Центросхідноєвропейський. Райони: Новом., Магд., Царич. Зрідка, переважно по узліссях заплавних дібров, лісових галявин. Екотонофіл. Потребує охорони як характерний елемент лучнолісових екотонів.

10. Chaerophyllum prescottii DC. - Бутень Прескотта. Східноєвропейсько-південносибірський. Район: Магд. Екотонофіл. Вид, дуже схожий на попередній за еколого-ценотичним спектром, але з деякими виразними морфологічними відмінностями (в деяких системах не визнається окремим видом). У Приоріллі достовірним є один локалітет біля с. Йосипівка на південно-східному прирічковому 


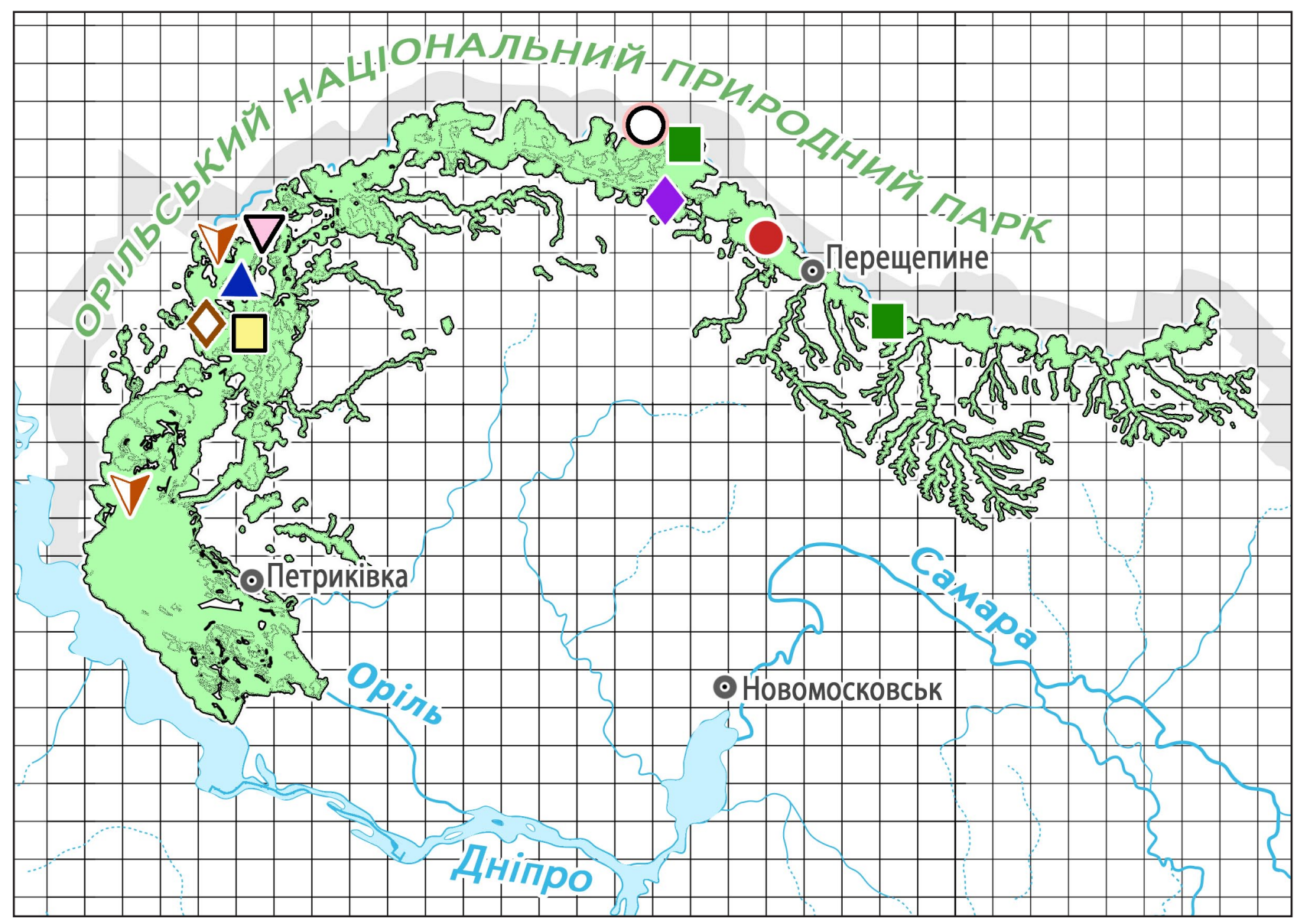

Рис. 1. Місця знахідок рідкісних видів Аріасеае на території Орільського національного парку:

$\nabla$-Angelica palustris; $\mathbf{\square}$-Angelica sylvestris; $\diamond$ - Bupleurum tenuissimum; $\bigcirc$ - Chaerophyllum prescottii; $\vee$-Cnidium dubium; $\diamond$ - Pastinaca sativa L. (subsp. sylvestris); $\bullet$ - Peucedanum ruthenicum;

$\boldsymbol{\Delta}$ - Selinum carvifolia; $\square-$ Seseli pallasii.

узліссі діброви прируслового типу. Обидва види (Ch. bulbosum et Ch. prescotii) потребують подальшого вивчення. Потребує охорони, як і попередній вид.

11. Chaerophyllum temulum L. - Бутень n'янкий. Європейський. Райони: Юр., Новом., Магд., Царич., Петрик. Неморальний. Ценофіл із розширеним спектром. По всій території, часто в лісах. Популяції стабільні. Охорони не потребує.

12. Cicuta virosa L. - Цикута отруйна. Палеарктичний. Райони: Магд., Петрик. Дуже вірогідно також у Новом. і Петрик. Повітряноводно-болотяний, лімнофільний. Рідко. Ценофіл із широким спектром. Популяції нечисленні. Потребує подальших досліджень. Підлягає охороні на регіональному рівні як характерний вид природних гігро-гідрофільних оселищ.

13. Cnidium dubium (Schkuhr) Thell. - Стожильник сумнівний. Західноєвразійський. Район: Царич. Рідкісний у Степовому Подніпров'ї вид. Для Приорілля
$€$ лише одне літературне згадування у О. Л. Бельгарда (1950) для ок. с. Катеринівка Царичанського району. Узлісно-лучний. У 2015 р. знайдено ценопопуляцію цього виду у північній частині Царичанського району, на вологій лісовій галявині (в ок. с. Бабайківка). Червона книга Дніпропетр. обл. («невизначений»).

14. Conium maculatum L. - Болиголов плямистий. Західноєвразійський. Райони: Юр., Новом., Магд., Царич., Петрик. Облігатний рудерант. Зрідка по всій території, біля ферм та на смітниках.

15. Daucus carota L. - Морква дика. Середньоазійсько-середземноморсько-понтичноєвропейський. Райони: Юр., Новом., Магд., Царич., Петрик. Рудерально-лучний. Дуже поширений по всій території, широкоамплітудний, але переважно по остепнених і слабозасолених луках, лучних степах iз різним ступенем антропогенного навантаження. Не потребує охорони.

16. Eryngium campestre L. - Миколайчики польові. Західнономадійський (паннонсько-понтичний). Рай- 
они: Юр., Новом., Магд., Царич., Петрик. Степовий рудерант. По всій території у степових оселищах, часто. Не потребує охорони.

17. Eryngium planum L. - Миколайчики плоскі. Східноєвропейсько-південносибірсько-номадійський. Лучний. Райони: Юр., Новом., Магд., Царич., Петрик. Зрідка по всій території, на ділянках із розвиненим лучним і лучно-дібровним заплавним комплексом - часто. Потребує охорони як важливий елемент лучних фітоценозів.

18. Falcaria vulgaris Bernh. - Різак звичайний. Центросхідноєвропейсько-середземноморськономадійський. Райони: Юр., Новом., Магд., Царич., Петрик. Лучно-степовий. По всій території, звичайно. Не потребує охорони.

19. Heracleum sibiricum L. - Борщзівник сибірський. Євробореально-східноєвропейськопівденносибірський. Райони: Юр., Новом., Магд., Царич., Петрик. Лучний. На свіжих, вологих і заболочених луках, по берегах водойм, у тальвегах балок, по узліссях, а також в угрупованнях рудерантів. Звичайно по всій території.

20. Oenanthe aquatica (L.) Poir. - Омег водяний. Райони: Юр., Новом., Магд., Царич., Петрик. Болотяно-водний (палюдант, аерогідрофіт). Європейсько-південносибірський (за іншими джерелами євразійський). По еутрофних мілководних стоячих водоймах (рис. 2, i), по відгалуженнях русла і мулистих мілинах р. Оріль, по замулених ділянках русел річок Прядівка, Заплавка (особливо в пониззях). Звичайно. Ценофіл, едифікатор специфічних омегових угруповань. Потребує охорони як ценозоутворювач.

21. Pastinaca sativa L. - Пастернак посівний (Pastinaca sativa subsp. sylvestris (Mill.) Rouy \& E.G. Camus - пастернак дикий). Південносибірськоєвропейський сполучний. Райони: Магд., Петрик. Лучний (лучно-лісовий за В. В. Тарасовим (2005). У даному списку враховувалися тільки природні популяції, відповідні обсягу таксона Pastinaca sylvestris Mill., який не визнається самостійним видом згідно з міжнародною базою номенклатурних назв The Plant List, а лише дикою формою пастернаку посівного. Достовірно відома тільки одна ценопопуляція з високотравної заболоченої луки в підніжжі привододільного схилу на лівому березі р. Оріль біля с. Бузівка (рис. 1). Дуже вірогідне зростання цього виду по вогких берегах дренажних канав та по сагах у Петриківському районі, на ділянці між pp. Дніпро та Протовч. Очевидно, що вид поширений і на інших ділянках долини. Рекомендується вне- сти до переліку видів, що потребують охорони на регіональному рівні (зі статусом «невизначений»).

22. Peucedanum alsaticum L. (Xanthoselinum alsaticum (L.) Schur) - Смовдь ельзаська (смовдь Любименка, золота смовдь). Центросхідноєвропейськономадійський. Райони: Юр., Новом., Магд., Царич., Петрик. Узлісно-лучний. Ценофіл із розширеним спектром. На заплавних луках Приорілля звичайний вид, але зі спорадичним траплянням. Нерідко утворює щільні високі зарості, у 2015 р. на різних ділянках проектованого національного парку спостерігалося масове квітування із формуванням характерного аспекту (наприклад, біля сс. Великокозирщина, Краснопілля, Гнатівка, Бабайківка). Рекомендується взяти під охорону як важливий ценоелемент лучних фітоценозів.

23. Peucedanum arenarium Waldst. \& Kit. (Taeniopetalum arenarium (Waldst. \& Kit.) V.N. Tichomirov) - Смовдь піскова. Балкано-східноєвропейськомалоазійський. Псамофільно-степовий. Райони: Магд., Царич., Петрик. Рідко зустрічається на відкритих піщаних кучугурах або у розріджених борах із великими відкритими галявинами. Потребує подальшого вивчення. Рекомендується додати до Червоного списку Дніпропетр. обл. зі статусом «рідкісний».

24. Peucedanum latifolium DC. - Смовдь иироколиста. Східнопонтичний. Райони: Юр., Новом., Магд., Царич., Петрик. Галофільно-лучний. На слабосолонцюватих заплавних луках, часто. У 2015 р. на багатьох ділянках спостерігалося масове квітування і формування аспекту лук у липні (рис. 2, к). Потребує охорони як важливий елемент природних лучних фітоценозів.

25. Peucedanum oreoselinum (L.) Moench-Cмовдb гірська. Європейський (південний субелемент). Райони: Юр., Новом., Магд., Царич., Петрик. Неморальнобореальний. У верхній частині долини - рідко, від Магдалинівського району до Петриківського включно - досить часто по всій території, внутрішній рисунок ареалу в басейні р. Оріль загалом повторює поширення острівних борових лісових масивів. У старих борах із присутністю листяних порід у підліску, суборах, на піщаних грунтах. У Петрик. районі (в межиріччі Протовчі-Орелі) подекуди утворює зріджені зарості на відкритих ділянках пісків із бореальнопсамофільно-степовим комплексом видів. Ценофіл 3 широким спектром. Потребує охорони як важливий елемент борових фітоценозів на південній межі їх природного поширення.

26. Peucedanum ruthenicum M. Bieb. - Смовдb руська (рис. 2, 3). Східноєвропейський. Район: Новом. 

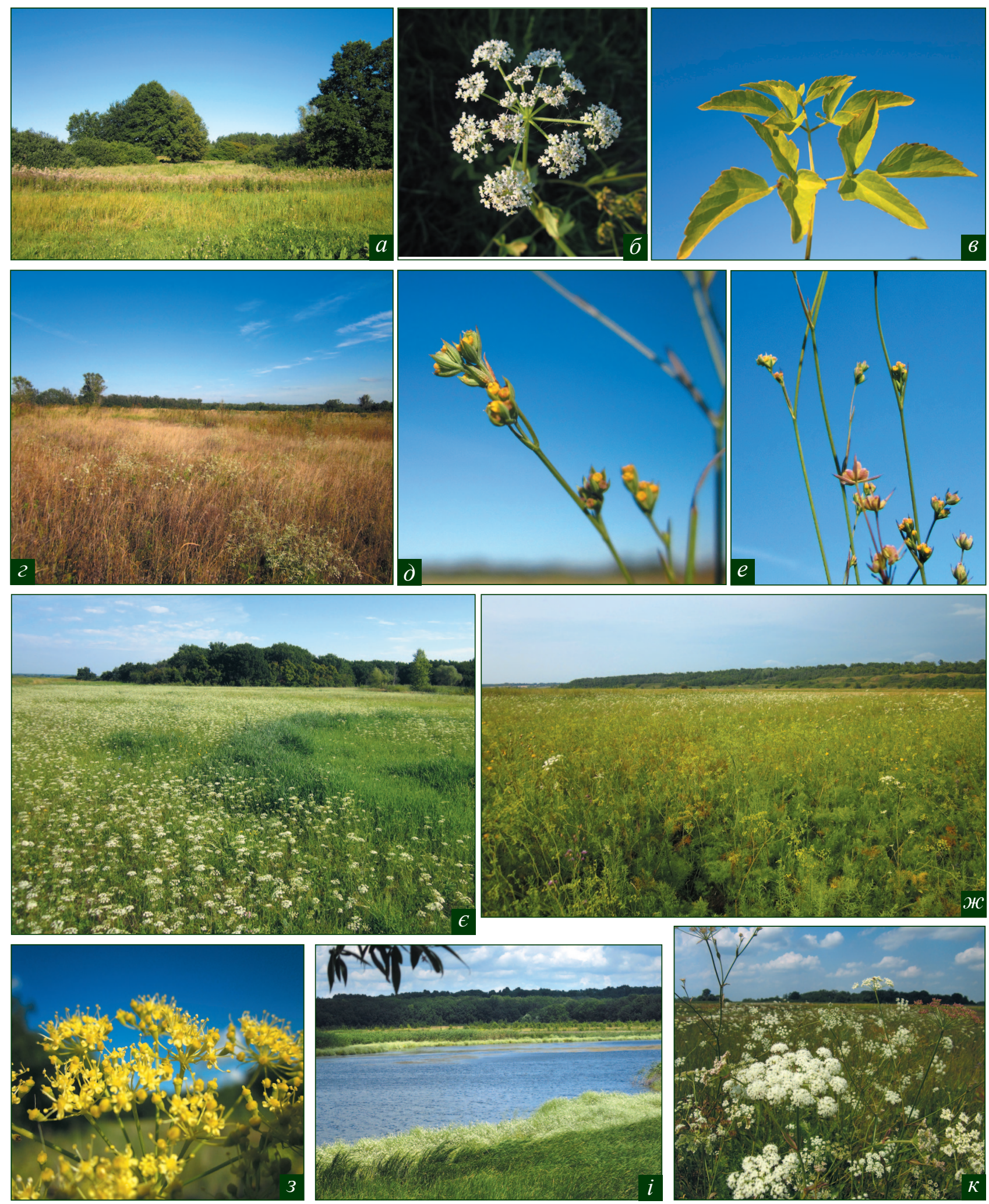

Рис. 2. Представники Аріасеае у проектованому національному природному парку «Орільський»:

Angelica palustris: а) загальний вид оселища; б) квітучий зонтик; в) лист рослини;

Bupleurum tennuisimum: г) загальний вид оселища; д) частина суцвіття; е) суцвіття та достигаючі супліддя.

Аспекти Apiaceae на луках: є) Pimpinella saxifraga; ж) Sium silaus ssp. besserii; з) квітучий зонтик Peисеdanum ruthenicum на луці біля с. Малокозирщина; і) облямівкові угруповання Oenanthe aquatica на Жуковім лимані; к) аспект Peucedanum latifolium на солонцюватій луці. 
Степовий (у Приоріллі - на луці). Дуже рідко. Відоме єдине місцезнаходження з куртини дорослих, генеративних рослин на сухуватій, солонцюватій луці, виявлене у липні 2015 р. у межах дібровно-лучного комплексу в заплаві р. Оріль (ок. с. Малокозирщина Новомоск. району, рис. 1). Рекомендується до внесення до Червоного списку Дніпропетр. обл. (зі статусом «рідкісний»).

27. Pimpinella saxifraga L. - Бедринецьь ломикаменевий. Європейсько-південносибірський. Райони: Юр., Новом., Магд., Царич., Петрик. Часто, однак не рівномірно по території проектованого національного парку. Трапляється у трьох різних формаціях - на заплавних луках, по степових схилах балок і корінного берега р. Оріль, і в соснових лісах арени, що вимагає детальніших еколого-морфологічних досліджень популяцій i визначення ступеня однорідності популяцій. У липні 2015 р. спостерігалося масове квітування і утворення аспекту на великих площах сіножатних лук біля с. Йосипівка (смуга між прирусловими дібровами і сосновим бором, рис. 2, є). Потребує охорони як важливий елемент природних фітоценозів різних типів.

28. Selinum carvifolia (L.) L. - Гірча кминолиcma. Європейський. Район: Царич. Лісо-лучний. На початку серпня 2015 р. нечисленну ценопопуляцію квітучих та вегетуючих рослин було знайдено на підлісній луці біля межі Дніпропетровської та Полтавської областей, на північ від с. Бабайківка Царичанського району (рис. 1). У В. В. Тарасова (2005) цей вид для Дніпропетровської області наводиться лише за «Флорою УРСР, т. 7» (1955), однак в оригіналі останнє джерело не містить згадувань для Дніпропетровської області, тому знахідку 2015 p. можливо розглядати як першу достовірну для цього виду як у Приоріллі, так і в Дніпропетровській області в цілому. Потребує подальших досліджень. Необхідно віднести до Червоного списку Дніпропетр. обл. (зі статусом «зникаючий»).

29. Seseli campestre Besser - Жабриия рівнинна. Східноєвропейсько-малоазійський. Райони: Юр., Новом., Магд., Царич., Петрик. Степовий (лучностеповий). На лесовосуглинкових степових ділянках, звичайно по всій території, у Петриківському - тільки у північній частині, зрідка. Не потребує спеціальної охорони.

30. Seseli libanotis (L.) W. D. J. Koch subsp. intermedium (Rupr.) P. W. Ball-Жабриия порізникова (порізник проміжний). Свразійський у широкому розумінні (східноєвропейсько-середньоазійськономадійсько-південносибірський за Ю. Д. Клеоповим (1990). Райони: Юр., Новом., Магд., Царич.,
Петрик. Зрідка, переважно поодиноко, очевидно, по всій території проектованого парку. Достовірно у 2015 р. спостерігався в Юр’ївському та Царичанському районах, на луках в долині р. Оріль. Тяжіє до лучних узлісь. Для визначення необхідності розроблення консерваційних заходів для цього виду необхідні додаткові дослідження.

31. Seseli pallasii Besser - Жабриця Паласа. Балкано-західнопонтичний ендем. Район: Царич. Петрофільний, кальцефільний. Сдине згадування для Приорілля наводиться В.В. Тарасовим (2005) за його гербарними зборами 1997 р. (с. Бабайківка Царичан. p-ну). Подальше перебування і поширення виду в межах проектованого національного парку «Орільський» потребує подальшого вивчення. Червона книга Дніпропетр. обл. («невизначений»).

32. Seseli tortuosum L. - Жабриия звивиста. Східнопонтичний ендем. Райони: Юр., Новом., Магд., Царич., Петрик. Псамофільно-степовий. Постійний елемент псамофільно-степових фітоценозів, у північно-східній частині парку рідко; від гирла р. Берестова і до гирла р. Оріль - по аренах часто, у Петриківському районі, на арені Дніпра - звичайно. Таксономічний статус неоднозначний і потребує подальших досліджень. Потребує охорони як ендемічний елемент псамофільних аренних степів.

33. Silaum silaus (L.) Schinz \& Thell. - Морківник лучний (морківник звичайний). Європейськопівденносибірський. Райони: Юр., Новом., Магд., Царич., Петрик. Галофільно-лучний. Звичайний по всій території вид, один із домінантів галофільних лук (рис. 2, ж), дуже поширених по долині р. Оріль. Рекомендується взяти вид під охорону як один із важливих едифікаторів природних лучних фітоценозів.

34. Sium latifolium L. - Вех широколистий. Європейсько-південносибірський. Райони: Юр., Новом., Магд., Царич., Петрик. Водно-болотний. У прибережній смузі повітряно-водної рослинності по берегах водойм різних типів, а також по заболочених луках, в заростях очерету, звичайно. Не потребує спеціальної охорони.

35. Sium sisarum L. (f. Sium sisaroideum DC.) - Bex сизаровидний. Південно-палеарктичний. Райони: Юр., Новом., Магд., Царич., Петрик. Лучно-болотяний. Вид, схожий на попередній, але зі зміщенням ценоспектра від аквальних до лучних мезогігрофільних оселищ. Поширений по всій території. На деяких вогких луках (по лучно-болотяних екотонах, наприклад, по краях зарослих очеретом та рогозом саг на давніх терасах) утворює достатньо щільні зарості, під час квітування в 2015 р. утворював виразний аспект (наприклад, в урочищі Яновщина неподалік 
с. Ковпаківка Магдалин. району). Рекомендується охороняти на регіональному рівні як характерний вид природних гігрофільних фітоценозів.

36. Torilis japonica (Houtt.) DC. - Ториліс японський. Свропейський. Райони: Юр., Новом., Магд., Царич., Петрик. Рудерально-лісовий. По всій території, зрідка. Переважно у листяних лісах із розбалансованим деревостаном і невиразною ценотичною будовою (штучні, після вибіркових рубок тощо). Статус не визначений.

37. Trinia multicaulis Schischk. - Тринія багатостеблова. Паннонсько-причорноморсько-прикаспійська група геоелементів Євразійського степового типу за Л. І. Крицькою і В. В. Новосадом (Krytsjka L. I. \& Novosad V. V., 2012). Райони: Юр., Новом. Степовий (на лесово-суглинистих грунтах, виходах осадових палеоген-неогенових та четвертинних порід (пісків, супісків, суглинків). На крутосхилах правого берега p. Оріль (дуже рідко), а також по деяких балках басейну р. Багатенька (рідко), достовірно відомий лише 3 північно-східних околиць проектованого національного парку. Рекомендується віднести до Червоного списку рослин Дніпропетр. обл. зі статусом «рідкісний».

\section{Еколого-географічний аналіз флори селерових (Аріасеае) проектованого національного парку «Орільський»}

Представники родини селерових (Арiaceae) мають дуже велике значення у формуванні рослинного покриву території проектованого національного парку «Орільський», межі якого згідно $з$ науковим обгрунтуванням мають охоплювати усі ділянки зі збереженою природною та напівприродною рослинністю по всьому басейну р. Оріль (в межах Дніпропетровської області). На заплавних солонцюватих луках селерові є домінантами, субдомінантами або асектаторами (3 високою щільністю ценопопуляцій) багатьох типів угруповань, і нерідко утворюють щільні зарості. Під час масового квітування такі види формують власні фізіономічні аспекти лук, які додають особливого колориту долинно-терасовим ландшафтам Приорілля у літній період. До цієї групи лучних аспектоутворювачів слід віднести п'ять видів (розташовані нижче за зростанням галофільності): Pimpinella saxifraga L., Eryngium planum L., Peucedanum alsaticum L., Peucedanum latifolium DC., Silaum silaus (L.) Schinz \& Thell. На обмежено поширених, рідкісних для регіону луках суббореального типу аналогічну роль виконують Angelica palustris (Besser) Hoffm., Selinum carvifolia (L.) L., котрі є дуже рідкісними видами для регіону і перебувають тут на південній межі при- родного ареалу. Усі види лучної ценогрупи - виразні ценофіли. Показово, що всі види лучного ценотипу належать до однієї групи географічних елементів - європейсько-південносибірського (європейськозахідносибірського).

Група гігрофільних видів охоплює п'ять видів 3 однієі триби (Oenantheae). 3 них Oenanthe aquatica (L.) Poir. є специфічним едифікатором групи асоціацій омегово-водяних боліт, які дуже поширені на різних ділянках Орільського національного парку i $\epsilon$ невід'ємною ланкою у природному гігроморфному сукцесійному ряді. Три інші гігрофільні види (Sium latifolium L. Sium sisarum L. i Berula erecta (Huds.) Coville) поширені повсюдно, але не надто численні й найчастіше виконують асектаторну роль в різних навколоводних і лучно-болотяних угрупованнях без чіткої ценотичної спеціалізації. Щодо берули прямої, до цього часу для Приорілля цей вид не наводився, хоча за першими даними, отриманими у 2015 р., може виявитися досить звичайним видом, а ії відсутність у флористичних звітах може пояснюватися морологічною подібністю до близьких генетично видів роду Sium. П'ятий вид, Cicuta virosa L. трапляється спорадично i поодиноко, ценотична приуроченість нечітка, зі стратегією реліктового виду. Аналіз географічних ареалів показує наявність у цій групі рівної кількості видів із широким палеарктичним типом ареалу та 3 європейсько-південносибірським, аналогічним попередній групі пратантів. Віднесення ж берули до європейського типу ареалу (за літературними даними) неоднозначне, i зрештою цей вид також може бути насправді ближчим до палеарктичного геоелемента.

У групі сильвантів представлено вісім видів Apiaceae: Aegopodium podagraria L., Aethusa cynapium L., Anthriscus cerefolium (L.) Hoffm., Anthriscus sylvestris (L.) Hoffm., Chaerophyllum temulum L., Torilis japonica (Houtt.) DC., Peucedanum oreoselinum (L.) Moench $i$ Pimpinella saxifraga L. Більшість із них мають європейський тип ареалу, що цілком відповідає їх ценотичній ролі в лісах Приорілля. У той же час майже всі види цієї групи різною мірою є лісовими бур'янами, за винятком Aegopodium podagraria L. (виразний ценофіл) і Peucedanum oreoselinum (L.) Moench (дуже характерний, хоча й не численний вид ренатуралізованих аренних лісів Приорілля). У таких лісах часто можна зустріти й Pimpinella saxifraga L., який формує в Приоріллі дві різні ценоморфи суббореально-лісову і лучну. Близька до лісових i група мезофільних та гігрофільно-мезофільних узлісних видів, які представлені у Приоріллі чотирма видами - Angelica sylvestris L. Chaerophyllum 
bulbosum L., Chaerophyllum prescottii DC., Cnidium dubium (Schkuhr) Thell. Усі вони - або рідкісні, або дуже рідкісні види у Приоріллі. А от два наступні види, які належать до групи узлісно-лучних мезогігрофільних видів (Heracleum sibiricum L. і Pastinaca sativa L.), більш поширені по території проектованого парку. Але якщо перший з них - широкоамплітудний i ценотично не дуже розбірливий вид, то другий вельми вибагливий до біотопів i, відповідно, має спорадичний характер поширення.

У мезоксерофільному ряді видів Аріасеае досить відокремлена група лучно-степових ценотично нечітких видів із рудеральним відтінком (Daucus carota L., Eryngium campestre L., Falcaria vulgaris Bernh.) та типових степових, які, у свою чергу, представлені псамофільно-степовими ендемічними (Peucedanum arenarium Waldst. \& Kit. та Seseli tortuosum L.), i зонально-степовими елементами (Seseli campestre Besser, Trinia multicaulis Schischk.). Із них останній, дуже рідкісний для регіону вид, приурочений тільки до східної ділянки парку, єдиної ділянки, де в басейні p. Багатенька (ліва притока р. Оріль) представлені балкові степи самарського типу (перехідного від наддніпрянських до сіверськодонецьких), із рядом інших рідкісних степових видів. За характером ареалу рудеральні лучно-степові види належать до більш широкого європейсько-номадійського типу, а типові степові ценофіли - до східноєвропейськомалоазійського типу.

Зрештою, ще два види Аріасеае заслуговують окремої уваги. Перший з них - Peucedanum ruthenicum M. Bieb., відомий $з$ літератури як справжній степовий, знайдено у Приоріллі в дещо нетипових для нього умовах на солонцюватій заплавній луці. Другий вид - Bupleurum tenuissimum L. відомий переважно $з$ півдня України, де зростає по приморських галофільних степах, але так само цей вид трапляється і по кам'янистих оселищах Скандинавії. Знахідка цього виду у Приоріллі поряд 3 іншим петрофільно-кальцефільним і галофільним видом Seseli pallasii Besser може свідчити про особливий, реліктовий, характер усієї місцевості в околицях смт. Царичанка (долина р. Оріль на цій ділянці дуже широка). Проте для вагоміших висновків необхідні подальші дослідження цієї ділянки. Сдиний на теренах Приорілля облігатний рудеральний вид у флорі селерових - Conium maculatum L. належить до широкого західноєвразійського типу ареалу.

Висновки. На території проектованого національного природного парку «Орільський» зосереджено ценопопуляції 37 видів родини Аріасеае, що складає 75 \% усіх видів, представлених у спонтанній фракції флори Дніпропетровської області. 3 них п' ять видів занесені до Червоної книги Дніпропетровської області, ще вісім видів (Aethusa cynapium L., Bupleurum tenuissimum L., Cicuta virosa L. Pastinaca sativa L. Peucedanum arenarium Waldst. \& Kit. Peucedanum ruthenicum M. Bieb. Selinum carvifolia (L.) L. Trinia multicaulis Schischk.) необхідно віднести до регіонального Червоного списку за результатами досліджень поширення цих видів на території майбутнього національного парку і Приорілля в цілому. Крім того, необхідно ініціювати написання поновленого Червоного списку для Дніпропетровського регіону з урахуванням найновіших підходів до формування червоних списків (Bilz M. \& Kell S.P. et al, 2011), в якому обгрунтувати принципово новий підхід до охорони видів рослин на регіональному рівні. Зокрема, пропонується під охорону взяти також види, які є едифікаторами або характерними видами типових (не обов' язково рідкісних чи зникаючих) фітоценозів. Такий підхід відкриє значно більші можливості для збереження оселищ, а також розширить спектр уже напрацьованих раніше методів синфітосозологічної охорони біорізноманіття. Зокрема, за результатами вивчення ценотичної ролі селерових у фітоценозах Приорілля до переліку таких ценотично важливих видів пропонується віднести 11 видів рослин, а саме: Aegopodium podagraria L., Chaerophyllum bulbosum L., Chaerophyllum prescottii DC., Eryngium planum L., Oenanthe aquatica (L.) Poir., Peucedanum latifolium DC., Peucedanum oreoselinum (L.) Moench, Pimpinella saxifraga L., Seseli tortuosum L., Silaum silaus (L.) Schinz \& Thell. та Sium sisarum L. Таким чином, із 37 видів Аріасеае, виявлених у Приоріллі, спеціальній охороні загалом підлягають 24 види цієї родини.

\section{Бібліографічні посилання}

Akinfiev I.Y. 1889. Rastitielnost Yekatierinoslava v kontse piervoho stoletiia yeho sushchestvovaniia [Vegetation of Yekaterinoslav at the end of the first century of its existence]. Yekaterinoslav, 238 p. (in Russian).

Baranovsky B.O., Masyuk O.M., Zhikhareva A.V. 2015. Predstavnyky rodyny zlakovykh u flori dolyny r. Oril [Representatives of the family of Poaceae in the flora of Oril river valley]. Biodiversity and the role of animals in ecosystems: Materials of VIII International Conference. - Dnipropetrovsk: Lyra, 8-9 (in Ukrainian).

Baranovsky B., Manyuk V., Demyanov V., Chegorka P., Gritsan Yu. 2013. Suchasnyi ekolohichnyi stan baseinu richky Oril u konteksti stvorennia natsionalnoho pryrodnoho parku "Pryorilskyi" [Contemporary ecological statement of the Oril river basin in context of creation national nature park "Pryorilsky"]. News of Dnipropetrovsk State 
Agrarian and Economic University, 2 (32), 55-60 (in Ukrainian).

Belgard A.L., Kirichenko T.F. 1940. Liesa doliny r. Orieli [The forests of Oril River]. Bulletin of the Faculty of biology DSU. - Dnipropetrovsk, Issue 3, 48-62 (in Ukrainian).

Bilz, M., Kell S.P., Maxterd, N. and Lansdown, R.V. 2011. European Red List of Vascular Plants. Luxembourg: Publications Office of the European Union, 130 p.

Chervona knyha Ukrainy. Roslynnyi svit. 2009. [Red Data Book of Ukraine. Plants]. Ed. by Y.P. Didukh. - Kyiv: Hlobalkonsaltynh, 900 p. (in Ukrainian).

Didukh Y.P., Chusova O.O., Olshevska I.A., Polishchuk Y.V. 2015. River valleys as the object of ecological and geobotanical research. Ukr. Bot. J., 72(5), 415-430. doi:org/10.15407/ukrbotj72.05.415

Eliashevych O.A. 1937. Orelski luky [Meadows of Oril river]. Bulletin of the Dnipropetrovsk botanical garden. Dnipropetrovsk: DSU, 2, 3-34 (in Ukrainian).

Flora URSR. 1955. [Flora of the Ukrainian SSR]. Ed. by Klokov M.V., Visiulina O.D. Kyiv: Academy of Sciences of Ukrainian SSR, Vol. 7, 460-618 (in Ukrainian).

Krytsjka L.I., Novosad V.V. 2012. Heoharfichna struktura flory Kodymo-Ielanetskoho Pobuzhzhia (aboryhenna fraktsiia) [Geographic structure of flora Kodymo-Elanetsky Bug region (native fraction)]. Proceedings of the National Museum of Natural History, №10, 53-64 (in Ukrainian).

Kucherevskyi V.V. 2004. Konspekt flory Pravoberezhnoho stepovoho Prydniprovia [Conspect of flora of Right-bank side of steppe Dnieper]. Dnipropetrovsk: Prospect, 292 p. (in Ukrainian).

Kleopov Y.D. 1990. Analiz flory shyrokolistviennykh liesov yevropieiskoi chasti SSSR [Flora Analysis of European deciduous forests partial USSR.]. Kyev: Naukova Dumka, 352 p. (in Ukrainian).

Mosyakin S.L. et Fedoronchuk M.M. 1999. Vascular plants of Ukraine. A nomenclatural checklist, Kiev: M.G. Kholodny Institute of Botany, $346 \mathrm{p}$.

Sahalaiev V.A. 2004. Heohrafycheskii analiz aridnoi flory stiepiei i pustyn yuho-vostoka Yevropieiskoi chasti Rossii [Geographical analysis of the arid flora of steppes and deserts of the south-east of European Russia]. Proceedings of Volgograd State Pedagogical University, Issue 5, 27-43 (in Russian).

Sidorov V.M. 1897. Matierialy dlia izucheniia Yekatierinoslavskoi flory [Materials for studying of Ekaterinoslavska flora]. Botanical notes (Scripta botan.), Issue 14. St. Petersburg, 126 p. (in Russian).

Spalik K. \& Downie S.R. 2006. The evolutionary history of Sium sensu lato (Apiaceae): dispersal, vicariance, and domestication as inferred from ITS rDNA phylogeny. American Journal of Botany 93(5), 747-761. Retrieved from http://www.life.illinois.edu/downie/Sium.pdf

Hultén, E. \& Fries, M. 1986. Atlas of North European vascular plants: north of the Tropic of Cancer I-III. - Koeltz Scientific Books, Königstein.

Ivanov A.L., Guseva I.N. 2014. Heohrafycheskyi analyz lesnoi flori Tsentralnoho Predkavkazia. [Geographical analysis of forest flora of the Central Ciscaucasia]. The South of Russia: ecology, development, №1, 133-140 (in Russian).

Kucherov I.B. 2000. Konkrietnaia flora i suktsessionnaia sistema: hranitsy konkrietnykh flor s tochki zrieniia dinamichieskoi orhanizatsii rastitielnosti [The particular flora and succession system: the boundaries of the specific floras in terms of the dynamic organization of vegetation]. The News of VOOP, Issue 7. Retrieved from http://www. ecosystema.ru/voop/works/v07 01.htm

Manyuk V.V. 2000. Pryorillia yak oseredok zberezhennia roslynnoho bioriznomanittia natsionalnoho znachennia [Pryorillya as a center of plant biodiversity preservation of national values]. Proceeding of scientific and practical seminar, Dnipropetrovsk, 28-31 (in Ukrainian).

MoeselH. 1965. Vergleichende Chorologie der Zentraleuropischen Flora. Jena, 583 p.

Pestushko Y.I. 1937. Roslynnist zasolenykh gruntiv dolyny serednoho Dnipra (Ielysavetivsko-Kurylivskyi masyv) [Vegetation of saline soils of valley of middle Dnipro (Yelyzavetivsko-Kurilovsky tract]. Bulletin of the Dnipropetrovsk botanical garden. Dnipropetrovsk: DSU, 2, 65-92. (in Ukrainian).

Razumovsky S.M. 1981. Zakonomiernosti dinamiki biotsenozov [Laws of biocenoses dynamics]. Moscow: Science, 231 p. (in Russian).

Tarasov V.V. 2005. Flora of Dnipropetrovsk and Zaporizhia region. Vascular plants. Biological and environmental characteristic of species. Dnipropetrovsk: DSU, 276 p. (in Ukrainian).

The International Plant Names Index. Retrieved from http:// www.ipni.org/

The Plant List (2013). Version 1.1. Published on the Internet. Retrieved from http://www.theplantlist.org/1.1/browse/A/ Apiaceae/

Zernov A.S. 2010. Nekotoryie dyskussyonnyie voprosy heohraficheskoi struktury flory [Some of the discussion questions of the geographical structure of flora.] // Piatyie Liubishchevskiie chtieniia, 45-48 (in Russian). 